\title{
Increased circulating Tfh to Tfr ratio in chronic renal allograft dysfunction: a pilot study
}

Lin Yan ${ }^{1}$, Yamei $\mathrm{Li}^{1}$, Yi Li $\mathrm{i}^{1}$, Xiaojuan $\mathrm{Wu}^{1}$, Xianding Wang ${ }^{2}$, Lanlan Wang ${ }^{1}$, Yunying Shi ${ }^{3+}$ and Jiangtao Tang ${ }^{1 *^{*+}}$ (D)

\begin{abstract}
Background: T follicular helper (Tfh) cells play a control role in contribution of B cell differentiation and antibody production. T follicular regulatory (Tfr) cells inhibit Tfh-B cell interaction.

Methods: To identify whether circulating Tfh (cTfh) and Tfr (cTfr) cells contribute to chronic renal allograft dysfunction (CAD), 67 kidney transplant recipients (34 recipients with CAD, 33 recipients with stable function) were enrolled. The frequency of cTfh and cTfr cells, the level of serum CXCL13 were measured.

Results: The frequency of CTfr cells in CAD group was significantly lower than that in stable group $(0.31 \%$ vs $0.68 \%$, $P=0.002$ ). The cTfh to CTfr ratio in CAD group was significantly higher than that in stable group (55.4 vs $25.3, P=0.013$ ). Serum CXCL13 in CAD group was significantly higher than stable group ( $30.4 \mathrm{vs} 21.9 \mathrm{ng} / \mathrm{ml}, P=0.025$ ). After linear regression analysis, the cTfh to cTfr ratio was an independent risk factor for estimated glomerular filtration rate (eGFR) in recipients (standardized coefficient $=-0.420, P=0.012$ ). After logistic regression analysis, the cTfh to cTfr ratio was an independent risk factor for $\mathrm{CAD}(\mathrm{OR}=1.043,95 \% \mathrm{Cl}=1.004-1.085, P=0.031)$.
\end{abstract}

Conclusion: The imbalance between cTfh and cTfr cells contribute to the development of CAD.

Keywords: T follicular helper cells, T follicular regulatory cells, CTfh to CTfr ratio, CXCL13, Chronic renal allograft dysfunction

\section{Background}

The risk of acute rejection after kidney transplantation has been decreased with the development of immunosuppressant and transplant technique, while chronic renal allograft dysfunction (CAD) is still the main threat for long-term allograft survival rates. Antibody-mediated injury or rejection is the leading cause of late kidney allograft dysfunction $[1,2]$. Donor-specific antibodies (DSA) could identify patients at high risk for kidney allograft loss $[3,4]$. Avoiding the influence of humoral immune factors on allograft function could decline the risk of CAD.

The production of high affinity antibody in germinal center (GC) requires the help of T follicular helper (Tfh) cells [5]. Tfh cells in lymph node highly express C-X-C chemokine receptor 5 (CXCR5), programmed death 1

\footnotetext{
* Correspondence: tjtdrscu@126.com

${ }^{1}$ Department of Laboratory Medicine, West China Hospital, Sichuan

University, No.37 Guoxue Xiang, Wuhou District, Chengdu, Sichuan, China

Full list of author information is available at the end of the article
}

(PD-1) and inducible co-stimulator (ICOS) [6]. Tfh cells migrate into germinal centers via gradients of $\mathrm{C}-\mathrm{X}-\mathrm{C}$ chemokine ligand 3 (CXCL13) and initiate $\mathrm{B}$ cells to undergo proliferation, differentiation and somatic hypermutation [6]. Tfh differentiation relies on expression of B cell lymphoma 6 (Bcl-6), which promote ICOS and PD-1 expression [6]. It has been demonstrated that signal transducer and activator of transcription 3 (STAT3) is required for the differentiation of Tfh cells through the induction of Bcl-6 [7-10]. Bcl-6 within Tfh cells is negatively regulated by signal transducer and activator of transcription 5 (STAT5), which inhibit Tfh differentiation through increasing the expression of B lymphocyte-induced maturation protein 1 (Blimp-1) [11, 12].

Tfh cells could also migrate to the circulation as circulating Tfh (cTfh) cells. These circulating cells express lower amounts of the Tfh markers ICOS, CXCR5, PD-1 and $\mathrm{Bcl}-6$ than their germinal center counterparts and respond to $\mathrm{CXCL} 13$ chemokine gradients, moving back 
to a secondary lymphoid organ germinal center, where they may be involved in germinal center formation [6]. Whether serum CXCL13 level is associated with cTfh cells in kidney transplantation recipients is not clear.

A recently described $\mathrm{T}$ follicular regulatory (Tfr) cells has revealed a new means by which the $\mathrm{GC}$ reaction is controlled [13]. Tfr cells express high levels of CXCR5, which directs them to the GC to inhibit the interaction of Tfh and B cells. Tfr cells differ from Tfh cells by expressing foxkhead box P3 (FoxP3) and Blimp-1 [13]. The dynamic proportions of Th and Tfr cells precede the increase in GC-B cells and antibody production [13]. Whether the circulating Tfr (cTfr) cells or the cTfh to cTfr ratio is associated with CAD is not clear.

It is well-known that transforming growth factor beta (TGF- $\beta$ ) plays a critical role in immune regulation, particularly in generation, function and stabilization of regulatory $\mathrm{T}$ cells (Tregs) [14]. TGF- $\beta$ could also regulate the development of Tfh and Tfr cells. Schmitt et al. found that TGF $\beta$ could promote human Tfh cells differentiation through STAT3/STAT4-mediated signal pathway [8]. TGF- $\beta$ neutralization could partially weaken the inhibitory effect of Tfr cells on the proliferation and differentiation of Tfh cells and B cells [15]. TGF- $\beta$ could also contribute to the development of Tfr cells through promoting the generation and activation of Treg cells [16]. Therefore, it is needed to identify that whether the role of serum TGF- $\beta$ in kidney transplant recipients favoring immune regulation or immune reactivation.

It is not clear that whether the cTfh and cTfr cells, the cTfh to cTfr ratio, the expression of STAT3/STAT5 on $\mathrm{CD}^{+}{ }^{+} \mathrm{CXCR}^{+}{ }^{+}$cells, serum CXCL13 and TGF- $\beta$ are correlated with $\mathrm{CAD}$ in kidney transplant recipients. The aim of this study was to identity the possible association between these immune parameters and CAD, and further probe into the underlying mechanism of CAD.

\section{Methods \\ Patients}

The present study is a cross-sectional pilot study. Eightytwo kidney transplant recipients receiving living donor kidney in West China Hospital of Sichuan University were enrolled in this study from May 2016 to May 2017. All of the recipients with infection or autoimmune diseases at the time of analysis were excluded from this study. All of the heparin-anticoagulated whole blood from these patients were performed flow cytometry. Excluded the number of acquired target cell subsets less than 100 cells, 67 recipients were eventually included in the following analysis. Chronic allograft dysfunction was defined as estimated glomerular filtration rate $($ eGFR) $<60 \mathrm{ml} / \mathrm{min} /$ $1.73 \mathrm{~m}^{2}$ after 3 months of transplantation [17, 18]. Within the 67 recipients, 34 recipients suffered from CAD (defined as $\mathrm{CAD}$ group) and 33 had stable renal function (defined as stable group). Among the 34 recipients with CAD, 21 recipients had undergone biopsy. According to Banff-2015 [19], 13 recipients were defined as biopsy-proven rejection (BPR) with 11 antibody-mediated rejection (ABMR) and 2 $\mathrm{T}$ cell-mediated rejection (TCMR), 9 recipients were defined as non-rejection (4 interstitial fibrosis tubular atrophy, 3 transplant glomerulonephropathy, 1 BK virus nephropathy, 1 recurrent glomerulonephropathy). Only 6 of all recipients with CAD got DSA detection with the results of 5 positive and 1 negative. Fifty recipients of all got panel reactive antibodies (PRA) detection with the results of 35 positive and 15 negative. BPR, non-rejection, DSA, PRA were used for sub-group analysis.

\section{Immunosuppressive regimen}

All of 67 patients received basiliximab as prophylactic therapy. Forty-eight recipients received tacrolimus-based triple immunosuppressant regimen (tacrolimus + mycophenolate mofetil + prednisone); 12 recipients received sirolimusbased triple immunosuppressant regimen (sirolimus + mycophenolate mofetil + prednisone); 2 recipients received cyclosporine A-based triple immunosuppressant regimen (cyclosporine A + mycophenolate mofetil + prednisone); 5 recipients received the combined tacrolimus-minimized and sirolimus immunosuppressant regimen (tacrolimus + sirolimus + mycophenolate mofetil + prednisone). Tacrolimus dose was administered at $1.0-1.5 \mathrm{mg}$ bid. The tacrolimus-minimized regimen was $0.5 \mathrm{mg}$ bid. The dose of sirolimus was $1.0 \mathrm{mg}$ bid. Cyclosporine A was administered at $50-75 \mathrm{mg}$ bid. Mycophenolate mofetil (MMF) was administered at $750 \mathrm{mg}$ bid. The maintenance dose of prednisone was $5 \mathrm{mg}$ or $10 \mathrm{mg}$ qd.

\section{Flow cytometry}

To determine the percentage of $\mathrm{T}$ cell subsets, heparinanticoagulated whole blood were collected and stained with CD3-PerCP (BD Bioscience, New Jersey, US), CD4FITC (BD Bioscience, New Jersey, US), CXCR5-APC (Biolegand, California, US), PD-1-PE (eBioscience, California, US), ICOS-PE (eBioscience, California, US) and CD25APC (BD Bioscience, New Jersey, US). After fixed and permeabilized, samples were stained with FoxP3-PE (BD Bioscience, New Jersey, US), p-STAT3-PE (BD Bioscience, New Jersey, US), p-STAT5-PE (BD Bioscience, New Jersey, US) and p-STAT4-PE (BD Bioscience, New Jersey, US). After stimulation with phorbol 12-myristate 13-acetate (PMA) $(50 \mathrm{ng} / \mathrm{ml})$ (Sigma-Aldrich, US), ionomycin (1 $\mu \mathrm{g} /$ ml) (Sigma-Aldrich, US), and Golgi stop (BD Bioscience, New Jersey, US) for $5 \mathrm{~h}$, the fixation and permeablication were performed. Then samples were stained with IL-21PE (BD Bioscience, New Jersey, US). Samples were measured with FACS Canto II (BD Biosciences, New Jersey, US). Gating strategy used for the analysis of all immune parameters was shown in Additional file 1. 


\section{Bio-plex}

Serum samples were collected and stored at $-80{ }^{\circ} \mathrm{C}$ freezer until analysis. Human Premixed Multi-Analyte Kit was purchased from $R \& D$ Systems (Minneapolis, Minnesota, USA). Serum CXCL13 and TGF- $\beta$ were measured by Bio-Plex ${ }^{\oplus}$ suspension array system (Bio-Rad Laboratories Inc., California, USA). All samples were measured in duplicate. Four serum samples were excluded from this analysis as the volume were not enough for analysis. Two CXCL13 detection results were also excluded as they were reported with warning after bioplex analysis. Eventually, 61 results of CXCL13 and 63 results of TGF- $\beta$ were included in the following analysis.

\section{Laboratory assays}

Serum creatinine (Scr) was measured by picric acid method (Roche Diagnostics, Mannheim, Germany). The eGFR was calculated using the Modification of Diet in Renal Disease formula which was adjusted to Chinese [20]: eGFR $\left(\mathrm{ml} / \mathrm{min} / 1.73 \mathrm{~m}^{2}\right)=186 \times \mathrm{Scr}(\mathrm{mg} / \mathrm{dl})^{-1.154} \times$ age $^{-0.203} \times(0.742$ if female $) \times 1.233$.

\section{Statistics analysis}

Statistical analysis and graphics were performed using SPSS 21.0 (SPSSInc, Chicago, IL, US) and GraphPad Prism version 5.01 (GraphPad, Inc., La Jolla, CA). The Mann-Whitney U-test was utilized to identify differences in phenotype between different groups. Logistic regression was performed to assess the independent associations of immune-associated parameters, other clinical variables with CAD. Linear regression was used to assess the independent associations of immune-associated parameters, other clinical variables with eGFR. Chi-square test and Mann-Whitney U-test were used to compare the percentage of recipients with CAD between groups classified based on cTfh to cTfr ratio. Spearman correlation analysis was performed to assess the association between CXCL13 or TGF- $\beta$ and the phenotype of cTfh or cTfr cells. A twosided $p$-value $\leq 0.05$ was considered significant.

\section{Results}

\section{Demographic and clinical characteristics}

This study eventually enrolled in a total of 67 candidates. Within the 67 kidney transplant recipients, 34 recipients suffered chronic allograft dysfunction and 33 maintained stable renal function. The demographic and clinical characteristics in the present study were described in Table 1. There were no significant differences in age, gender, pre-PRA level, HLA mismatch and transplant duration time between CAD group and stable group. Sixty-two recipients received tacrolimus, sirolimus or cyclosporine A based immunosuppressive regiment combined with prednisone and mycophenolate mofetil. Five recipients received combined-use of calcineurin inhibitor (CNI) and sirolimus in CAD group. The use of immunosuppressant was statistically different between CAD group and stable group $(P=0.045)$. The eGFR level was significantly different between CAD group and stable group (median value: $33.2 \mathrm{vs} 74.1 \mathrm{ml} / \mathrm{min} / 1.73 \mathrm{~m}^{2}$, respectively, $P<0.001)$.

\section{Decreased frequency of cTfr cells and increased cTfh to cTfr ratio in CAD group}

The frequency of $\mathrm{CXCR}^{+}$on $\mathrm{CD}^{+}$cells was significantly lower in $\mathrm{CAD}$ group compared to stable group $(17.3 \%$ vs 22.2\%, $P=0.035)$. The frequency of cTfh cells $\left(\mathrm{CXCR}^{+} \mathrm{Foxp}^{-}\right.$on $\left.\mathrm{CD}^{+}\right)$had a lower trend in CAD group compared to stable group $(16.8 \%$ vs $21.2 \%, P=0.058$, Figs. 1a, 2a). The frequency of $\mathrm{cTfr}\left(\mathrm{CXCR} 5^{+} \mathrm{Foxp}^{+}\right.$on $\mathrm{CD}^{+}$) cells in CAD group was observed significantly lower

Table 1 Demographic and clinical characteristics

\begin{tabular}{|c|c|c|c|}
\hline & CAD group & Stable group & $P$-value \\
\hline & $N=34$ & $N=33$ & \\
\hline Age (range), years & $44(22-53)$ & $41(26-53)$ & 0.213 \\
\hline Male, percentage & $28,82 \%$ & $24,73 \%$ & 0.352 \\
\hline Pre-PRA (range), \% & $0(0-24.1)$ & $0(0-26.8)$ & 0.111 \\
\hline HLA mismatch (range) & $4(2-7)$ & $4(0-6)$ & 0.164 \\
\hline Transplant Duration (range), months & $55(6-132)$ & $36(6-108)$ & 0.089 \\
\hline Immunosuppressant & & & 0.045 \\
\hline --Tacrolimus & --21 & --27 & \\
\hline --Sirolimus & --7 & --5 & \\
\hline --Cyclosporine A & --1 & --1 & \\
\hline$--\mathrm{CNI}+$ Sirolimus & --5 & --0 & \\
\hline eGFR (range), $\mathrm{ml} / \mathrm{min} / 1.73 \mathrm{~m}^{2}$ & $33.2(4.8-58.9)$ & $74.1(60.9-121.6)$ & $<0.001$ \\
\hline
\end{tabular}

$P$-value $<0.05$ was shown in bold. Data were shown as Median (Range) or Number, percentage $C A D$ chronic allograft dysfunction, PRA panel reactive antibodies, CNI calcineurin inhibitor 
than that in stable group $(0.31 \%$ vs $0.68 \%, P=0.002$, Figs. $1 \mathrm{~b}, 2 \mathrm{~b})$. The cTfh to cTfr ratio was significantly higher in CAD group compared to stable group (55.4 vs 25.3, $P=0.013$, Fig. 2c). Tregs $\left(\mathrm{CD} 25^{+} \mathrm{Foxp}^{+}\right.$on $\left.\mathrm{CD} 4^{+}\right)$ showed the same trend as cTfr cells $(1.03 \%$ vs $1.66 \%$, $P=0.009$, Fig. 2d).

The differences of the frequency of $\mathrm{CXCR} 5{ }^{+} \mathrm{PD}-1^{+}$on $\mathrm{CD} 4^{+}$cells or PD- 1 expression on $\mathrm{CD} 4^{+} \mathrm{CXCR} 5^{+}$cells were not significant between $\mathrm{CAD}$ group and stable group (4.9\% vs $5.3 \%, P=0.607$, Fig. 2 e; $29.3 \%$ vs $29.1 \%$, $P=0.259$, Fig. 2f, respectively). Neither as the frequency of $\mathrm{CXCR}^{+} \mathrm{ICOS}^{+}$on $\mathrm{CD}^{+}$cells or ICOS expression on $\mathrm{CD}^{+} \mathrm{CXCR}^{+}$cells between $\mathrm{CAD}$ group and stable group $(0.66 \%$ vs $0.86 \%, P=0.135$, Fig. 2 g; $2.6 \%$ vs $3.6 \%$, $P=0.158$, Fig. 2h, respectively).

There was significantly lower frequency of $\mathrm{CXCR}^{+} \mathrm{STAT}^{+}{ }^{+}$on $\mathrm{CD}^{+}{ }^{+}$or $\mathrm{CXCR}^{+} \mathrm{STAT}^{+}$on $\mathrm{CD}^{+}$ cells in CAD group than patients with stable renal function ( $10.1 \%$ vs $17.2 \%, P<0.0001$, Fig. $2 \mathrm{i} ; 12.3 \%$ vs $18.5 \%, P=0.0002$, Fig. 2 j). The STAT3 expression on $\mathrm{CD}^{+} \mathrm{CXCR}^{+}$cells in CAD group was also significantly lower than that in stable group $(70.3 \%$ vs $86.4 \%, P=0.003$, Fig. 2k), while the expression of STAT5 on $\mathrm{CD}^{+}{ }^{+} \mathrm{CXCR}^{+}$cells had no significant differences between CAD group and stable group (84.3\% vs $88.1 \%$, $P=0.151$, Fig. 2l).

However, the frequency of $\mathrm{CXCR} 5^{+} \mathrm{STAT} 4^{+}$on $\mathrm{CD} 4^{+}$and the expression of STAT4 on $\mathrm{CD} 4^{+} \mathrm{CXCR} 5^{+}$ cells had no significant differences between CAD group and stable group $(0.29 \%$ vs $0.40 \%, P=0.159$, Fig. $2 \mathrm{~m} ; 2.0 \%$ vs $1.9 \%, P=0.855$, Fig. $2 \mathrm{n}$, respectively). Neither as the frequency of CXCR $5^{+} \mathrm{IL}-21^{+}$on $\mathrm{CD} 4^{+}$ cells or IL-21 expression on $\mathrm{CD} 4^{+} \mathrm{CXCR}^{+}$cells between CAD group and stable group $(1.11 \%$ vs $1.00 \%$, $P=0.624$, Fig. $20 ; 6.3 \%$ vs $7.5 \%, P=0.734$, Fig. 2 , respectively).

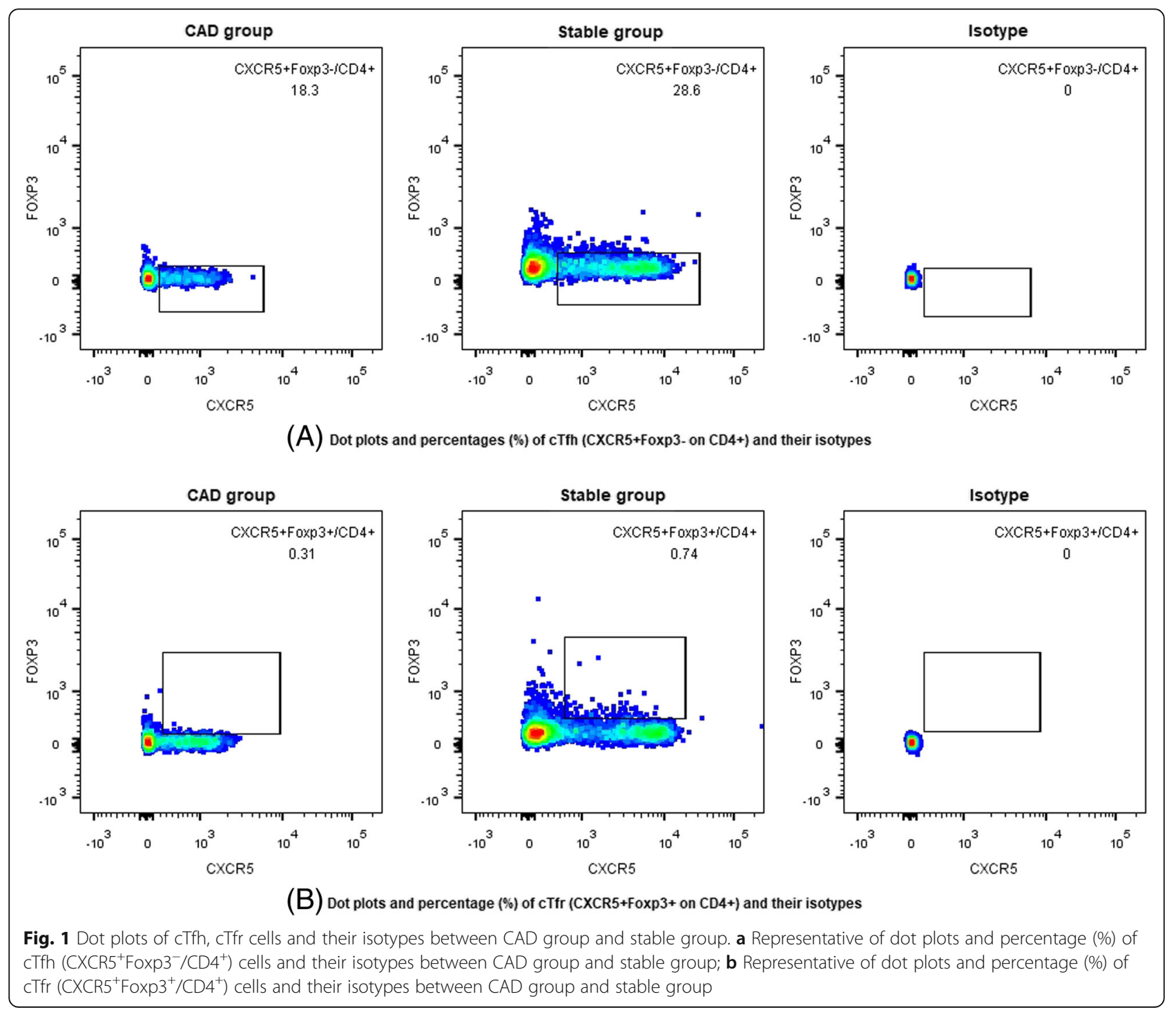




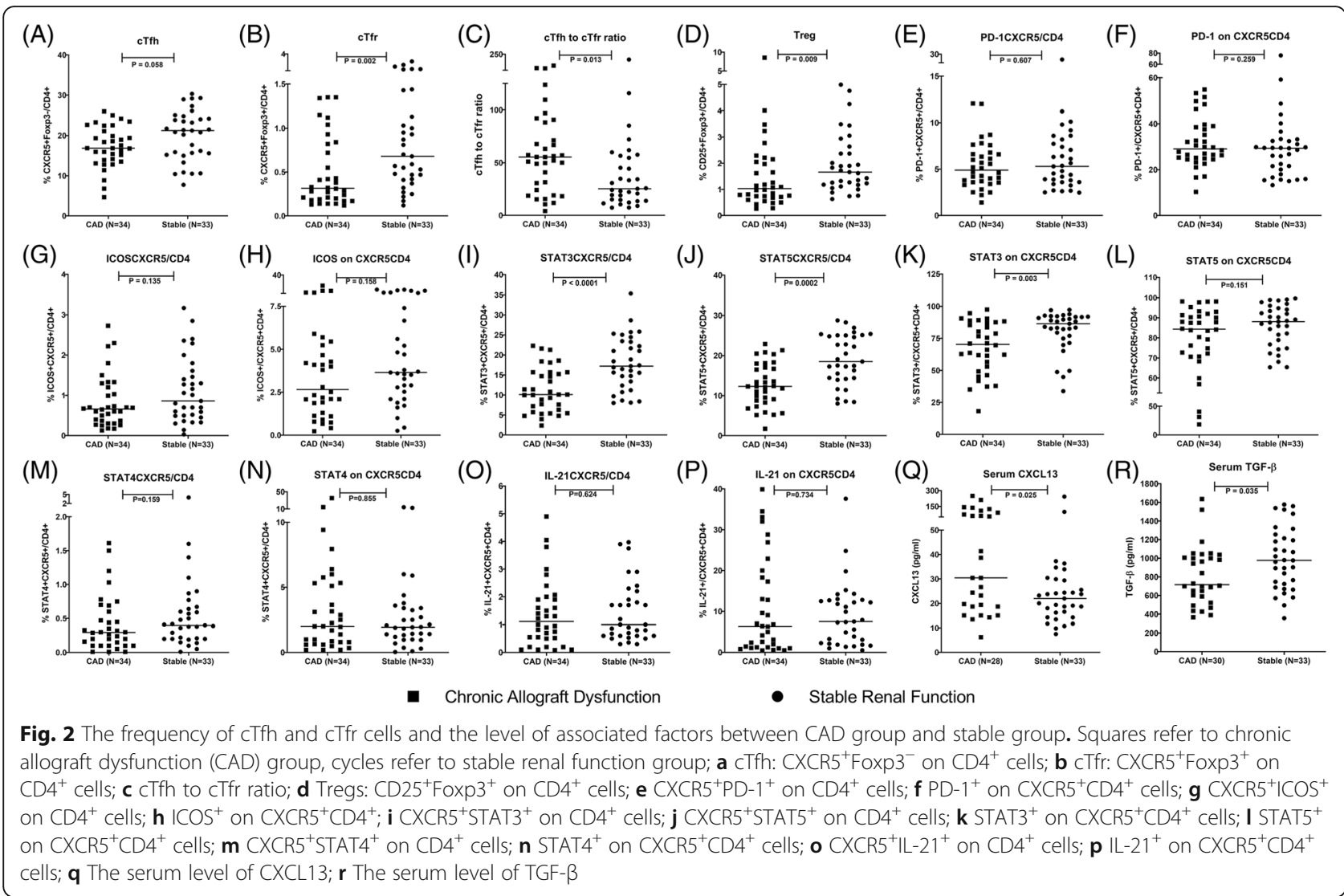

\section{Increased serum CXCL13 and decreased serum TGF- $\beta$ in CAD group}

Serum CXCL13 median level were $21.9(15.2-29.6) \mathrm{ng} / \mathrm{ml}$ in patients with stable renal function and 30.4 (18.7-86.9) $\mathrm{ng} / \mathrm{ml}$ in patients with CAD. Serum CXCL13 was significantly higher in CAD group when compared to stable group $(P=0.025$, Fig. $2 q)$. The median level of serum TGF- $\beta$ were 976 (704-1235) $\mathrm{pg} / \mathrm{ml}$ in patients with stable renal function and $716(572-1014) \mathrm{pg} / \mathrm{ml}$ in patients with CAD. It was significantly lower in CAD group compared to stable group ( $P=0.035$, Fig. 2 r).

\section{The cTfh to cTfr ratio was an independent risk factor to renal function and CAD}

In model 1, we assessed whether the association between immune parameters and eGFR remained independent of adjustment for age, gender, transplantation duration time, pre-PRA level, HLA mismatch and immunosuppressant. The cTfh to cTfr ratio, CXCR $5^{+} \mathrm{STAT}^{+}$on $\mathrm{CD} 4^{+}$cells, $\mathrm{CXCR}^{+} \mathrm{STAT}^{+}$on $\mathrm{CD} 4^{+}$cells, Tregs or CXCL13 was independent factor to eGFR (standardized coefficient $=-0.279, \quad P=0.030 ; \quad$ standardized coefficient $=0.328, P=0.007$; standardized coefficient $=0.327$, $P=0.008 ; \quad$ standardized coefficient $=0.399, \quad P=0.001$; standardized coefficient $=-0.380, P=0.006$, respectively).
To assess whether these five parameters were independent of each other, second regression analysis was performed after including these five parameters in one multiple linear regression analysis. The cTfh to cTfr ratio was observed an independent risk factor to declined eGFR (standardized coefficient $=-0.420, P=$ 0.012, shown in Table 2).

In model 2, we assessed whether the association between immune parameters and CAD remained independent of adjustment for age, gender, transplantation duration time, pre-PRA level, HLA mismatch and immunosuppressant. The cTfh to cTfr ratio, $\mathrm{CXCR} 5^{+} \mathrm{STAT}^{+}{ }^{+}$on $\mathrm{CD}^{+}$cells, $\mathrm{CXCR}^{+} \mathrm{STAT}^{+}{ }^{+}$on $\mathrm{CD} 4^{+}$cells, cTfr, Tregs or CXCL13 was independent factor to eGFR (standardized coefficient $=1.019, P=0.024$; standardized coefficient $=0.868, P=0.002$; standardized coefficient $=0.327$, $P=0.008 ;$ standardized coefficient $=0.250, \quad P=0.033$; standardized coefficient $=0.344, P=0.007$; standardized coefficient $=1.038, P=0.031$, respectively). Second regression analysis was also performed after including these six parameters in one multiple linear regression analysis. Transplantation duration and cTfh to cTfr ratio were independent risk factors to $\mathrm{CAD}(\mathrm{OR}=$ $1.042,95 \% \mathrm{CI} 1.007-1.078, P=0.018$; OR $=1.043,95 \% \mathrm{CI}$ $1.004-1.085, P=0.031$, shown in Table 2 ). 
Table 2 Multi-regression analysis

\begin{tabular}{|c|c|c|c|c|}
\hline \multicolumn{5}{|c|}{ Model 1 Linear regression analysis for eGFR } \\
\hline & \multicolumn{3}{|c|}{ Standardized coefficient } & $P$-value \\
\hline Gender & \multicolumn{3}{|c|}{-0.207} & 0.110 \\
\hline Age & \multicolumn{3}{|c|}{-0.193} & 0.225 \\
\hline Transplantation duration & \multicolumn{3}{|c|}{-0.191} & 0.195 \\
\hline Pre-PRA & \multicolumn{3}{|l|}{0.015} & 0.909 \\
\hline HLA mismatch & \multicolumn{3}{|l|}{0.025} & 0.852 \\
\hline Immunosuppressant & \multicolumn{3}{|l|}{0.094} & 0.548 \\
\hline cTfh to cTfr ratio & \multicolumn{3}{|c|}{-0.420} & 0.012 \\
\hline $\mathrm{CXCR}^{+} \mathrm{STAT3}^{+}$on $\mathrm{CD}^{+}$ & \multicolumn{3}{|c|}{-0.236} & 0.374 \\
\hline $\mathrm{CXCR}^{+} \mathrm{STAT5}^{+}$on $\mathrm{CD}^{+}$ & \multicolumn{3}{|l|}{0.273} & 0.269 \\
\hline Tregs & \multicolumn{3}{|l|}{0.101} & 0.533 \\
\hline CXCL13 & \multicolumn{3}{|c|}{-0.162} & 0.303 \\
\hline \multicolumn{5}{|c|}{ Model 2 Logistic regression analysis for CAD } \\
\hline & OR & \multicolumn{2}{|c|}{ OR 95\% Cl } & $P$-value \\
\hline Gender & 9.964 & 0.185 & 535.386 & 0.258 \\
\hline Age & 0.993 & 0.838 & 1.176 & 0.932 \\
\hline Transplantation duration & 1.042 & 1.007 & 1.078 & 0.018 \\
\hline Pre-PRA & 0.912 & 0.770 & 1.080 & 0.284 \\
\hline HLA mismatch & 0.827 & 0.397 & 1.722 & 0.612 \\
\hline Immunosuppressant & 0.541 & 0.106 & 2.750 & 0.459 \\
\hline cTfh to cTfr ratio & 1.043 & 1.004 & 1.085 & 0.031 \\
\hline $\mathrm{CXCR5}^{+} \mathrm{STAT3}^{+}$on $\mathrm{CD}^{+}$ & 1.093 & 0.733 & 1.628 & 0.663 \\
\hline $\mathrm{CXCR5}^{+} \mathrm{STAT5}^{+}$on $\mathrm{CD}^{+}$ & 0.760 & 0.492 & 1.174 & 0.216 \\
\hline Tregs & 0.971 & 0.276 & 3.417 & 0.963 \\
\hline cTfr & 3.304 & 0.029 & 375.073 & 0.621 \\
\hline CXCL13 & 1.023 & 0.968 & 1.082 & 0.415 \\
\hline
\end{tabular}

Model 1. $P$-value for linear regression equation was 0.004 by multiple linear regression analysis including age, gender, transplantation duration, Pre-PRA, HLA mismatch, immunosuppressant, cTfh to cTfr ratio, $\mathrm{CXCR5}^{+} \mathrm{STAT3}^{+}$on $\mathrm{CD}^{+}$ cells, $\mathrm{CXCR5}^{+} \mathrm{STAT5}^{+}$on $\mathrm{CD}^{+}$cells, Treg, CXCL13; Model 2. R square for logistic regression was 0.681 by multiple logistic regression analysis including age, gender, transplantation duration, Pre-PRA, HLA mismatch, immunosuppressant, cTfh to cTfr ratio, $\mathrm{CXCR5}^{+} \mathrm{STAT}^{+}$on $\mathrm{CD}^{+}$cells, $\mathrm{CXCR}^{+}{ }^{+} \mathrm{STAT}^{+}{ }^{+}$on $\mathrm{CD}^{+}$cells, CTfr, Treg, CXCL13; $P$-value $<0.05$ was shown in bold. Pre-PRA panel reactive antibodies prior to transplantation, OR odds ratio, $\mathrm{Cl}$ confidence intervals

\section{Stratified analysis of cTfh to cTfr ratio}

Based on the quartile of cTfh to cTfr ratio, the kidney transplant recipients were classified into four groups, Group 1 (ratio $\leq 16)$, Group $2(16<$ ratio $\leq 35)$, Group 3 $(35<$ ratio $\leq 60)$, Group 4 (ratio $>60)$. Within Group 1, Group 2, Group 3 or Group 4, the percentage of recipients with CAD was $33.3,33.3,64.7,70.6 \%$, respectively. The composition ratio of recipients with stable renal function and CAD within these four groups was significantly different $(P=0.046)$ by Chi-square test. Through post-hoc test by Mann-Whitney $U$ methods, the percentage of recipients with CAD in Group 4 was significantly higher than that in Group 1 and Group $2(P=0.038 ; P=0.030$, respectively, Table 3). No significant difference of the percentage of recipients with CAD between Group 1 and Group 2, Group 1 and Group3, Group 2 and Group 3, Group 3 and Group 4 was found $(P=1.000, P=0.081$, $P=0.067, P=0.718$, respectively).

\section{Correlation analysis of CXCL13 or TGF- $\beta$ for $\mathrm{cTfh}$ or $\mathrm{CTfr}$}

After correlation analysis, a negative association between serum CXCL13 and frequency of $\mathrm{CXCR}^{+}$on $\mathrm{CD}^{+}$cells was observed in kidney transplant recipients (spearman $r=-0.332 ; P=0.008$, Table 4 ). The frequency of cTfh cells was also negatively correlated with CXCL13 (spearman $r=-0.312 ; P=0.013$, Table 4). No association between serum CXCL13 and cTfr cells was observed (spearman $r=-0.108 ; P=0.435$, Table 4). No association between serum TGF- $\beta$ and $c$ Tfh, cTfr, CXCR $5^{+}$STAT3 ${ }^{+}$ on $\mathrm{CD}^{+}$cells, or Tregs was observed (Table 4).

\section{Sub-group analysis based on BPR, DSA and PRA}

When immune parameters were compared between BPR group and stable group, the percentage of cTfr, cTfh to cTfr ratio, the expression of ICOS, STAT3, STAT5 were significantly different (Fig. 3). The differences of other immune parameters were not significant (shown in Additional file 2). The percentage of cTfr, cTfh to cTfr ratio and ICOS expression was also significantly different between DSA positive group and stable group (Fig. 4, Additional file 3). The comparisons between non-rejection group and stable group, between non-rejection group and BPR group were also done. Only the percentage of $\mathrm{CXCR}^{+} \mathrm{STAT}^{+}$on $\mathrm{CD}^{+}$was found significantly different between non-rejection group and stable group (shown in Additional file 4). Only cTfh to cTfr ratio and ICOS expression were found significantly different between BPR group and non-rejection group (shown in Additional file 5). The analysis results between PRA positive group and PRA negative group had the same trend as comparison between CAD group and stable group (shown in Additional file 6). Patients with CAD $\left(e G F R<60 \mathrm{ml} / \mathrm{min} / 1.73 \mathrm{~m}^{2}\right)$ were divided into three groups: Group 1 with eGFR from 30 to $60 \mathrm{ml} / \mathrm{min} /$ $1.73 \mathrm{~m}^{2}(N=19)$; Group 2 with eGFR from 15 to $30 \mathrm{ml} /$ $\mathrm{min} / 1.73 \mathrm{~m}^{2}(N=12)$; Group 3 with eGFR less than 15 $\mathrm{ml} / \mathrm{min} / 1.73 \mathrm{~m}^{2} \quad(N=3)$. No significant differences of immune parameters were observed between these three groups (shown in Additional file 7).

\section{Discussion}

In the present study, we found that the frequency of $\mathrm{CXCR}^{+}$on $\mathrm{CD}^{+}$cells and cTfr cells were decreased in CAD group than stable group. The frequency of cTfh cells had the same trend. The cTfh to cTfr ratio in CAD group was higher than that in stable group. Serum CXCL13 in CAD group was higher than that in stable 
Table 3 Stratified analysis of cTfh to cTfr ratio

\begin{tabular}{|c|c|c|c|c|c|}
\hline & & Stable group & CAD group & Total & $P$-value \\
\hline \multirow[t]{2}{*}{ Group 1} & N & 10 & 5 & 15 & 1.000 (Group 1 vs Group 2) \\
\hline & Percentage & $66.7 \%$ & $33.3 \%$ & & 0.081 (Group 1 vs Group 3) \\
\hline \multirow[t]{2}{*}{ Group 2} & N & 12 & 6 & 18 & $\mathbf{0 . 0 3 8}$ (Group 1 vs Group 4) \\
\hline & Percentage & 66.75 & $33.3 \%$ & & 0.067 (Group 2 vs Group 3) \\
\hline \multirow[t]{2}{*}{ Group 3} & N & 6 & 11 & 17 & $\mathbf{0 . 0 3 0}$ (Group 2 vs Group 4) \\
\hline & Percentage & $35.3 \%$ & $64.7 \%$ & & 0.718 (Group 3 vs Group 4) \\
\hline \multirow[t]{2}{*}{ Group 4} & $\mathrm{~N}$ & 5 & 12 & 17 & \\
\hline & Percentage & $29.4 \%$ & $70.6 \%$ & & \\
\hline \multirow[t]{2}{*}{ Total } & N & 33 & 34 & 67 & \\
\hline & Percentage & $49.3 \%$ & $50.7 \%$ & & \\
\hline$P$-value & 0.046 & & & & \\
\hline
\end{tabular}

Group 1 (cTfh to cTfr ratio $\leq 16$ ); Group 2 ( $16<$ cTfh to cTfr ratio $\leq 35$ ); Group 3 ( $35<$ cTfh to cTfr ratio $\leq 60$ ); Group 4 (cTfh to cTfr ratio > 60). P-value < 0.05 was shown in bold

group. Serum CXCL13 was negatively associated with the frequency of cTfh cells. No association between serum CXCL13 and cTfr cells was observed. Serum TGF$\beta$ in CAD group was lower than that in stable group. No association between serum TGF- $\beta$ and cTfh, cTfr, or $\mathrm{CXCR}^{+} \mathrm{STAT}^{+}$on $\mathrm{CD}^{+}$cells was observed. The cTfh to cTfr ratio was an independent risk factor to renal function and CAD after multiple regression analysis. After stratified analysis based on the cTfh to cTfr ratio, the percentage of recipients with CAD in Group 4 was significantly higher than that in Group 1 and Group 2. The cTfh to cTfr ratio was also significantly higher in BPR group or DSA group compared to stable group.

The proportions of both cTfh and cTfr cells in recipients with CAD were lower than that in recipients with stable renal function. Tfh and Tfr cells share a lot of common differentiation signal pathway. Bcl-6 is a key transcription factor for the differentiation of Tfh and Tfr cells $[6,13]$. Tfh and Tfr cells express CXCR5 and migrate into GC under the gradient of CXCL13 [6, 13]. Interleukin-2 (IL-2) could inhibit the differentiation of Tfh and Tfr cells through STAT5Blimp-1 signal pathway [21-23]. A recent study

Table 4 Correlation analysis of CXCL13 or TGF- $\beta$ for CTfh or CTfr

\begin{tabular}{llll}
\hline & & Spearman $r$ & $P$-value \\
\hline CXCL13 & CXCR5 $^{+}$on CD4 & \\
CXCL13 & CTfh & -0.332 & $\mathbf{0 . 0 0 8}$ \\
CXCL13 & CTfr & -0.312 & $\mathbf{0 . 0 1 3}$ \\
TGF- $\beta$ & CTfh & -0.108 & 0.435 \\
TGF- $\beta$ & CTfr & 0.158 & 0.209 \\
TGF- $\beta$ & CXCR5 $^{+}$STAT3 $^{+}$on CD4 & \\
TGF- $\beta$ & Tregs $^{+}$ & 0.249 & 0.064 \\
\hline
\end{tabular}

$P$-value $<0.05$ was shown in bold demonstrated that RNA-binding protein (Roquin) could inhibit the differentiation from Naïve $T$ cells to Tfh cells, while inhibit the conversion of Treg to Tfr cells through inhibiting protein kinase B signal pathway [24]. Several studies have demonstrated that STAT3 was indispensable for Tfh and Tfr cell differentiation by inducing the expression of Bcl-6 during immunization or infection $[9,10,25,26]$. Therefore, it is probably that the increased number of Tfh cells would be accompanied with the increase of Tfr cells in kidney transplant recipients.

We found that serum CXCL13 in CAD group was significantly higher than that in stable group and high expression of serum CXCL13 is negatively associated with the frequency of cTfh cells. Havenar-Daughton et al. demonstrated in mouse, macaques model and HIVinfected human that plasma CXCL13 levels correlated with GC activity in draining lymph nodes [27]. Mabuka et al. found that early serum CXCL13 but not B cell frequency could predict the later emergence of detectable HIV neutralizing antibodies [28]. cTfh cells could migrate into GC via CXCL13 gradient, which might contribute to the lower frequency of cTfh cells in CAD group, initiate the GC formation, and promote the humoral immune response. Dedeoglu et al. recently demonstrated that the frequency of $\mathrm{CD} 4^{+} \mathrm{T}$ cells within $\mathrm{CD}^{+} \mathrm{T}$ cells in lymph node from end-stage renal disease (ESRD) patients was significantly higher than that in peripheral blood [29]. Tfh or Tfr cells, as a main subset of $\mathrm{CD}_{4}^{+} \mathrm{T}$ cells within GC, their frequency in GC was also probably higher than that in circulation, particularly under the chemotaxis of high level of CXCL13.

The cTfh to cTfr ratio was an independent risk factor to renal function and CAD after multiple regression analysis. The proportion of Tfh and Tfr cells is 


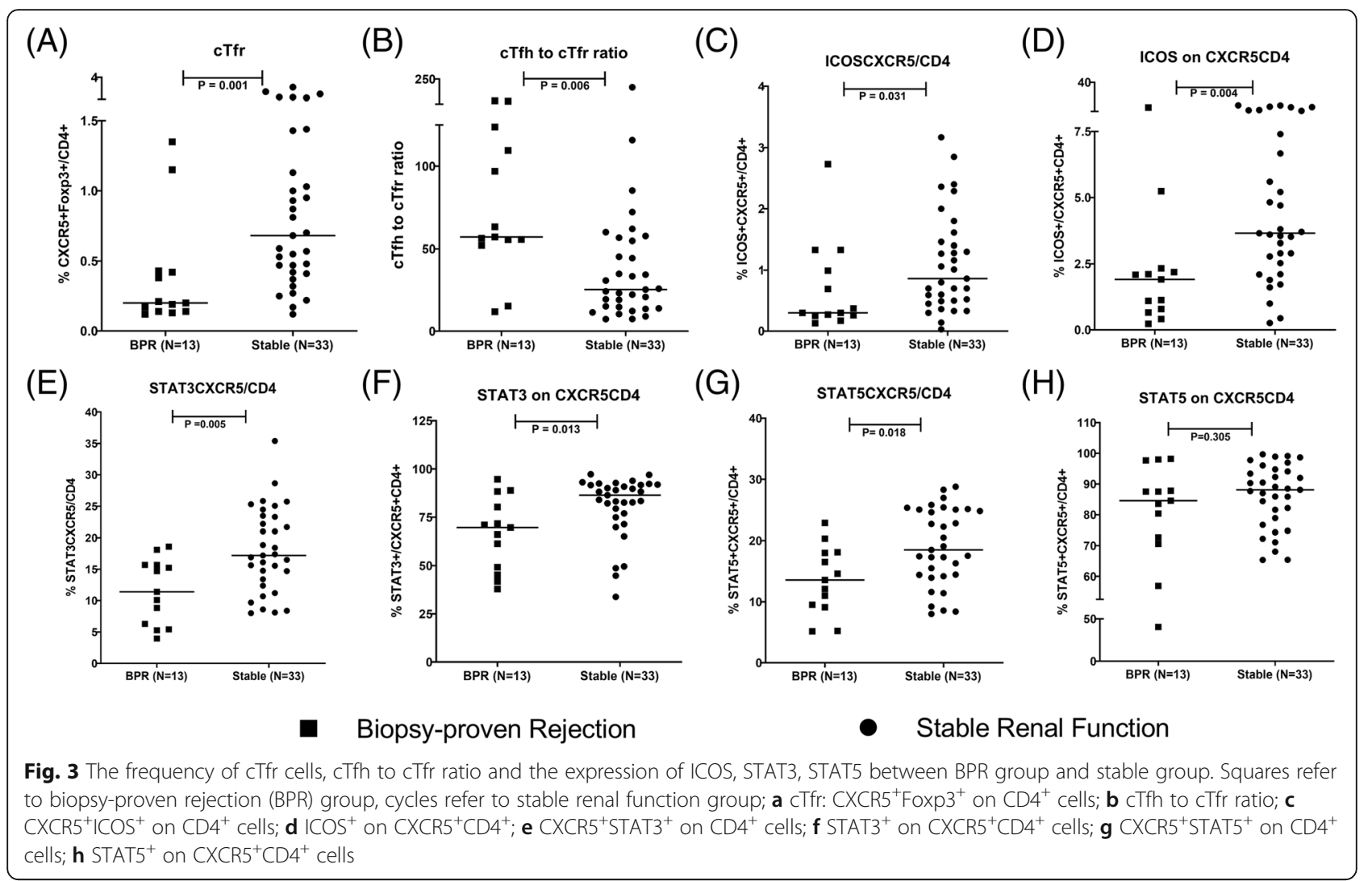

dramatically changed. In skin-draining lymph nodes without antigen stimulation, Tfr cells constitute approximately $50 \%$ of all $\mathrm{CD} 4^{+} \mathrm{CXCR}^{+}$cells. Seven days after stimulation, Tfr cells comprised only approximately $20 \%$ of the $\mathrm{CD}^{+} \mathrm{CXCR}^{+}$population [13]. When there was influenza infection, Tfr cells was approximately $5-8 \%$ of $\mathrm{CD}^{+}{ }^{+} \mathrm{CXCR} 5^{+}$cells [13]. Constant allograft antigen stimulation would make the imbalance between Tfh cells to Tfr cells, dysregulation of humoral immunity, and eventually lead to allograft rejection.

After stratified analysis based on the cTfh to cTfr ratio, the percentage of recipients with CAD in Group 4 was significantly higher than that in Group 1 and Group 2. The Tfh to Tfr ratio has been demonstrated to act as a biomarker of humoral immunity. Fan et al. recently demonstrated in a simian immunodeficiency virus-infected (SIV) rhesus macaques model that the Tfh to Tfr ratio in peripheral lymphatic tissues is critical for regulating autoreactive antibody production in chronic SIV infection [30]. Xu et al. found that the cTfh to cTfr ratio was associated with disease activity in systemic lupus erythematosus [25]. The cTfh to cTfr ratio indicated ectopic lymphoid structure formation in minor salivary gland, strongly associated with B cell, $\mathrm{CD}_{4}^{+} \mathrm{T}$ cell, and $\mathrm{PD}-1^{+} \mathrm{ICOS}^{+}$
$\mathrm{T}$ cell infiltration in minor salivary gland and allowed discrimination between Sjogren's syndrome patients and healthy donors [31]. Chen et al. showed that the frequency of cTfr cells and the number of Tfr cells in renal graft tissues in ABMR group were significantly lower than that of non-ABMR group, although no cTfh to cTfr ratio was analyzed [15]. In the present study, we found that the cTfh to cTfr ratio was significantly higher in recipients with ABMR or DSA than recipients with stable renal function. The cTfh to cTfr ratio is a potential biomarker for kidney transplant recipients with CAD, ABMR and the production of DSA and might identify recipients at the risk of allograft failure.

No association between serum TGF- $\beta$ level and cTfh cells nor $\mathrm{CXCR}^{+} \mathrm{STAT}^{+}$on $\mathrm{CD}^{+}{ }^{+} \mathrm{T}$ cells was observed. Serum TGF- $\beta$ has a trend to be positively associated with cTfr cells. As it has been reported, TGF- $\beta$ could not only contribute the Tfh differentiation but also Tfr production $[8,15,16]$. Tfh and Tfr cells are activated in germinal canter, which might explain why serum TGF- $\beta$ did not significantly affect the frequency of cTfh and cTfr cells in kidney transplant recipients.

This study has some limitations. Only the percentage of each cell subset was detected, but not the cell 

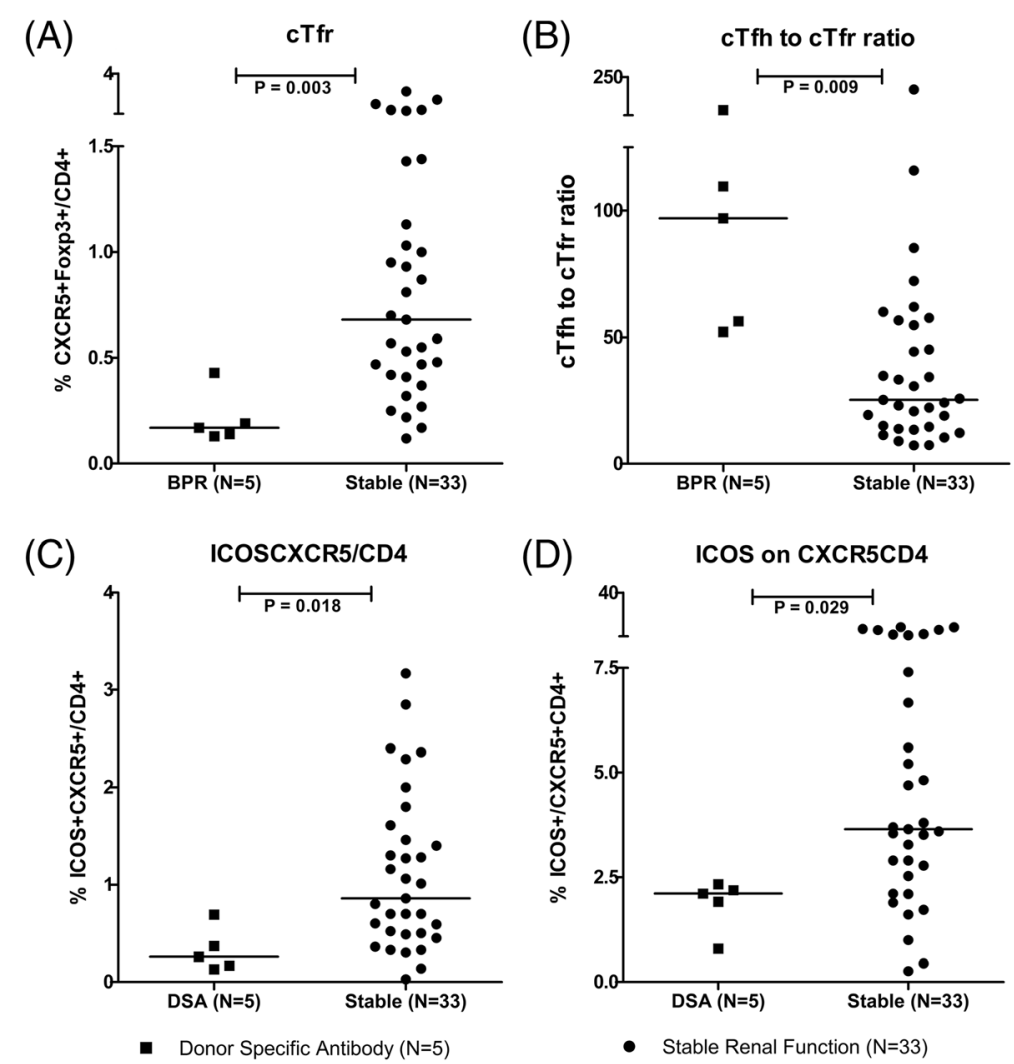

Fig. 4 The frequency of cTfr cells, cTfh to cTfr ratio and the expression of ICOS between DSA positive group and stable group. Squares refer to donor specific antibody (DSA) group, cycles refer to stable renal function group; a cTfr: CXCR5 ${ }^{+}$Foxp3 $^{+}$on $\mathrm{CD}^{+}$cells; $\mathbf{b}$ cTfh to cTfr ratio; $\mathbf{c}$ $\mathrm{CXCR5}^{+} \mathrm{ICOS}^{+}$on $\mathrm{CD}^{+}$cells; $\mathbf{d} \mathrm{ICOS}^{+}$on $\mathrm{CXCR5}^{+} \mathrm{CD} 4^{+}$

function. The analysis of donor-specific immune cell would be better than the cell phenotyping for organ transplantation. In our previous study [32], we already found that donor-specific IL-21 producing cells at 6 months after kidney transplantation could predict rejection within 5 years, while cTfh or cTfr cells was not found to be associated with rejection. In the present study, cTfr cells and cTfh to cTfr ratio correlated with rejection, but not IL-21. Donor-specific IL-21 producing cells might be more sensitive in rejection prediction than cTfh and cTfr. However, with the prolonged transplant duration time, the expression of cTfh and cTfr might be changed. The different degree of CXCR5 ${ }^{+}$ cells migrating to GC and allograft might lead to different outcomes. Considering the detection difficulty of donor-specific IL-21 producing cells, the cTfh to cTfr ratio might be more potential as a biomarker of CAD in kidney transplant recipients.

\section{Conclusion}

The circulating Tfh to Tfr ratio was an independent risk factor for recipients with chronic renal allograft dysfunction. Serum CXCL13 level was negatively correlated with cTfh cells. Whether the cTfh to cTfr ratio and CXCL13 could predict the risk of CAD in kidney transplant recipients requires to be further clarified.

\section{Additional files}

Additional file 1: Figure S1. Gating strategy used for the analysis of all immune parameters. (A) CXCR5 and Foxp3 Gating Strategy; (B) CXCR5 and PD-1 Gating Strategy; (C) CXCR5 and ICOS Gating Strategy; (D) CXCR5 and STAT3 Gating Strategy; (E) CXCR5 and STAT4 Gating Strategy: (F) CXCR5 and STAT5 Gating Strategy; (G) CXCR5 and IL-21 Gating Strategy. (JPG $3945 \mathrm{~kb}$ )

Additional file 2: Figure S2. The frequency of cTfh cells and the level of associated-factor between BPR group and stable group. Squares refer to biopsy-proven rejection (BPR) group, cycles refer to stable renal function group; (A) CTfh: CXCR5 ${ }^{+} \mathrm{Foxp}^{-}$on $\mathrm{CD}^{+}$cells; (B) Tregs: $\mathrm{CD}^{2} 5^{+} \mathrm{Foxp3}^{+}$on $\mathrm{CD}^{+}$cells; (C) CXCR5 ${ }^{+} \mathrm{PD}-1^{+}$on $\mathrm{CD} 4^{+}$cells; (D) PD- $1^{+}$on $\mathrm{CXCR5}{ }^{+} \mathrm{CD} 4^{+}$cells; (E) $\mathrm{CXCR5}^{+} \mathrm{STAT4} 4^{+}$on $\mathrm{CD}^{+}$cells; (F) STAT4 ${ }^{+}$on $\mathrm{CXCR5}^{+} \mathrm{CD} 4^{+}$cells; (G)

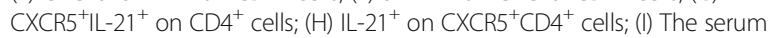
level of CXCL13; (J) The serum level of TGF- $\beta$. (JPG $1525 \mathrm{~kb}$ )

Additional file 3: Table S1. Mann-Whitney $U$ analysis between recipients with DSA and stable renal function. $P<0.05$ were shown in bold. (DOCX $15 \mathrm{~kb}$ )

Additional file 4: Table S2. Mann-Whitney $U$ analysis between recipients with stable renal function and non-rejection. $P<0.05$ were shown in bold. (DOCX $15 \mathrm{~kb}$ )

Additional file 5: Table S3. Mann-Whitney $U$ analysis between recipients with biopsy-proven rejection and non-rejection. $P<0.05$ were shown in bold. (DOCX $15 \mathrm{~kb}$ ) 
Additional file 6: Figure S3. The frequency of cTfh and cTfr cells and the level of associated-factor between PRA positive group and PRA negative group. Squares refer to panel reactive antibodies positive (PRA) group, cycles refer to panel reactive antibodies negative group; (A) CTfh: $\mathrm{CXCR5}^{+} \mathrm{Foxp}^{-}$on $\mathrm{CD}^{+}$cells; (B) CTfr: $\mathrm{CXCR5}^{+} \mathrm{Foxp}^{+}$on $\mathrm{CD} 4^{+}$cells; (C) CTfh to CTfr ratio; (D) Tregs: CD25 ${ }^{+}$Foxp3 $3^{+}$on CD4 ${ }^{+}$cells; (E) CXCR5 ${ }^{+}$PD- $1^{+}$ on $\mathrm{CD}^{+}$cells; (F) PD- $1^{+}$on $\mathrm{CXCR}^{+} \mathrm{CD}^{+}$cells; (G) $\mathrm{CXCR5}^{+} \mathrm{CCOS}^{+}$on $\mathrm{CD}^{+}$ cells; (H) ICOS ${ }^{+}$on $\mathrm{CXCR5}^{+} \mathrm{CD}^{+}$; (I) $\mathrm{CXCR5}^{+} \mathrm{STAT3}^{+}$on $\mathrm{CD}^{+}$cells; (J) $\mathrm{STAT3}^{+}$on $\mathrm{CXCR5}^{+} \mathrm{CD}^{+}$cells; (K) CXCR5 ${ }^{+} \mathrm{STAT4}^{+}$on $\mathrm{CD}^{+}$cells; (L) $\mathrm{STAT}^{+}$on $\mathrm{CXCR5}^{+} \mathrm{CD} 4^{+}$cells; (M) CXCR5 ${ }^{+} \mathrm{STAT}^{+}$on $\mathrm{CD} 4^{+}$cells; (N) $\mathrm{STAT5}^{+}$on CXCR5 ${ }^{+} \mathrm{CD} 4^{+}$cells; (O) CXCR5 ${ }^{+} \mathrm{IL}-21^{+}$on $\mathrm{CD} 4^{+}$cells; (P) IL-21 $1^{+}$ on $\mathrm{CXCR5}^{+} \mathrm{CD} 4^{+}$cells; (Q) The serum level of CXCL13; (R) The serum level of TGF- $\beta$. (JPG $2686 \mathrm{~kb}$ )

Additional file 7: Table S4. Kruskal-Wallis $\mathrm{H}$ analysis of immune parameters between three groups of recipients with CAD divided by eGFR. Thirty-four patients with CAD (eGFR< $\left.60 \mathrm{ml} / \mathrm{min} / 1.73 \mathrm{~m}^{2}\right)$ were divided into three groups: Group 1 with eGFR from 30 to $60 \mathrm{ml} / \mathrm{min} / 1.73 \mathrm{~m}^{2}$ ( $\left.N=19\right)$; Group 2 with eGFR from 15 to $30 \mathrm{ml} / \mathrm{min} / 1.73 \mathrm{~m}^{2}(\mathrm{~N}=12)$; Group 3 with eGFR less than $15 \mathrm{ml} / \mathrm{min} / 1.73 \mathrm{~m}^{2}(\mathrm{~N}=3)$. (DOCX $\left.15 \mathrm{~kb}\right)$

\section{Abbreviations}

ABMR: Antibody-mediated rejection; Bcl-6: B cell lymphoma 6; Blimp-1: B lymphocyte-induced maturation protein 1; BPR: Biopsy-proven rejection; CAD: Chronic renal allograft dysfunction; CNI: Calcineurin inhibitor; CTfh: Circulating Tfh; CTfr: Circulating Tfr; CXCL13: C-X-C chemokine ligand 3; CXCR5: C-X-C chemokine receptor 5; DSA: Donor-specific antibodies; eGFR: Estimated glomerular filtration rate; ESRD: End-stage renal disease; FoxP3: Foxkhead box P3; GC: Germinal center; ICOS: Inducible co-stimulator; MMF: Mycophenolate mofetil; PD-1: Programmed death 1; PMA: Phorbol 12myristate 13-acetate; PRA: Panel reactive antibodies; Scr: Serum creatinine; SIV: Simian immunodeficiency virus; STAT3: Signal transducer and activator of transcription 3; STAT5: Signal transducer and activator of transcription 5; TCMR: T cell-mediated rejection; Tfh cells: T follicular helper cells; Tfr cells: T follicular regulatory cells; TGF- $\beta$ : Transforming growth factor beta; Tregs: Regulatory T cells

\section{Acknowledgements}

The authors would like to thank the technicians from the Department of Laboratory Medicine and the nephrologist from Department of Nephrology in West China Hospital for their contributions to this study.

\section{Authors' contributions}

$L Y, Y M L$ and XJW performed experiments; $L Y, Y M L, Y L$ analyzed data and made the figures; $L Y$, and $Y L$ wrote the article; $Y Y S$ and JTT interpreted the results. XDW and YYS collaborated in patient collection; LLW, YYS and JTT designed the research. All authors have read and approved the manuscript.

\section{Funding}

This research is supported by the National Natural Science Foundation of China (No. 81571561, No. 81771714, No.81871713) and 1.3.5 project for disciplines of excellence, West China Hospital, Sichuan University (No. ZYJC18004) in the design, analysis and interpretation of the data.

\section{Availability of data and materials}

The datasets used in the current study are available from the corresponding author on reasonable request.

\section{Ethics approval and consent to participate}

All procedures performed in this study involving human participants were in accordance with the ethical standards of the institutional and/or national research committee and with the 1964 Helsinki declaration and its later amendments or comparable ethical standards. This study was approved by the ethics committee of West China Hospital (2017-397). Informed consent was written for this study and obtained from all individual participants included in the study.

\section{Consent for publication}

All authors have approved the manuscript being submitted and agreed to its publication to this journal.

\section{Competing interests}

The authors declare that they have no competing interests.

\section{Author details}

${ }^{1}$ Department of Laboratory Medicine, West China Hospital, Sichuan University, No.37 Guoxue Xiang, Wuhou District, Chengdu, Sichuan, China. ${ }^{2}$ Department of Urology, West China Hospital, Sichuan University, Chengdu, China. ${ }^{3}$ Department of Nephrology, West China Hospital, Sichuan University, Chengdu, China.

Received: 16 December 2018 Accepted: 24 July 2019 Published online: 05 August 2019

\section{References}

1. Einecke G, Sis B, Reeve J, Mengel M, Campbell PM, Hidalgo LG, et al. Antibody-mediated microcirculation injury is the major cause of late kidney transplant failure. Am J Transplant. 2009;9:2520-31.

2. Gaston RS, Cecka JM, Kasiske BL, Fieberg AM, Leduc R, Cosio FC, et al. Evidence for antibody-mediated injury as a major determinant of late kidney allograft failure. Transplantation. 2010;90:68-74.

3. Loupy A, Lefaucheur C, Vernerey D, Prugger C, Duong van Huyen JP, Mooney N, et al. Complement-binding anti-HLA antibodies and kidneyallograft survival. N Engl J Med. 2013;369:1215-26.

4. Guidicelli G, Guerville F, Lepreux S, Wiebe C, Thaunat O, Dubois V, et al. Non-complement-binding De novo donor-specific anti-HLA antibodies and kidney allograft survival. J Am Soc Nephrol. 2016;27:615-25.

5. Yan $L$, de Leur $K$, Hendriks RW, van der Laan LJW, Shi Y, Wang $L$, et al. T follicular helper cells as a new target for immunosuppressive therapies. Front Immunol. 2017:8:1510.

6. Walters GD, Vinuesa CG. T follicular helper cells in transplantation. Transplantation. 2016;100:1650-5.

7. Ray JP, Marshall HD, Laidlaw BJ, Staron MM, Kaech SM, Craft J. Transcription factor STAT3 and type I interferons are corepressive insulators for differentiation of follicular helper and T helper 1 cells. Immunity. 2014;40:367-77.

8. Schmitt N, Liu Y, Bentebibel SE, Munagala I, Bourdery L, Venuprasad K, et al. The cytokine TGF-beta co-opts signaling via STAT3-STAT4 to promote the differentiation of human TFH cells. Nat Immunol. 2014;15:856-65.

9. Choi YS, Yang JA, Crotty S. Dynamic regulation of Bcl6 in follicular helper CD4 T (Tfh) cells. Curr Opin Immunol. 2013:25:366-72.

10. Read KA, Powell MD, Oestreich KJ. T follicular helper cell programming by cytokine-mediated events. Immunology. 2016;149:253-61.

11. Johnston RJ, Choi YS, Diamond JA, Yang JA, Crotty S. STAT5 is a potent negative regulator of TFH cell differentiation. J Exp Med. 2012;209:243-50.

12. Nurieva RI, Podd A, Chen Y, Alekseev AM, Yu M, Qi X, et al. STAT5 protein negatively regulates $T$ follicular helper (Tfh) cell generation and function. J Biol Chem. 2012;287:11234-9.

13. Sage PT, Sharpe AH. T follicular regulatory cells. Immunol Rev. 2016;271:246-59.

14. Horwitz DA, Zheng SG, Wang J, Gray JD. Critical role of IL-2 and TGFbeta in generation, function and stabilization of Foxp3+CD4+ Treg. Eur J Immunol. 2008;38:912-5.

15. Chen W, Bai J, Huang H, Bi L, Kong X, Gao Y, et al. Low proportion of follicular regulatory $T$ cell in renal transplant patients with chronic antibodymediated rejection. Sci Rep. 2017;7:1322.

16. Li L, Yang SH, Yao Y, Xie YQ, Yang YQ, Wang YH, et al. Block of both TGFbeta and IL-2 signaling impedes Neurophilin-1(+) regulatory $T$ cell and follicular regulatory T cell development. Cell Death Dis. 2016;7:e2439.

17. Hosseinzadeh M, Ahmadpoor P, Yekaninejad MS, Pourrezagholi F, Foroughi F, Ghorbanpour M, et al. Expression patterns of toll like receptor (TLR)-2, TLR-4 and myeloid differentiation primary response gene 88 (MYD88) in renal transplant patients developing allograft dysfunction; a cohort study. Transpl Immunol. 2018;48:26-31.

18. KDIGO. Managing your adult patients who have a kidney transplant. https:// kdigo.org/guidelines/transplant-recipient/.

19. Bruneval P, Angelini A, Miller D, Potena L, Loupy A, Zeevi A, et al. The XIllth Banff conference on allograft pathology: the Banff 2015 heart meeting report: improving antibody-mediated rejection diagnostics: strengths, unmet needs, and future directions. Am J Transplant. 2017;17:42-53.

20. Ma YC, Zuo L, Chen JH, Luo Q, Yu XQ, Li Y, et al. Modified glomerular filtration rate estimating equation for Chinese patients with chronic kidney disease. J Am Soc Nephrol. 2006;17:2937-44. 
21. Ballesteros-Tato A, Leon B, Graf BA, Moquin A, Adams PS, Lund FE, et al. Interleukin-2 inhibits germinal center formation by limiting $T$ follicular helper cell differentiation. Immunity. 2012;36:847-56.

22. Linterman MA, Toellner KM. TFR cells trump autoimmune antibody responses to limit sedition. Nat Immunol. 2017;18:1185-6.

23. Botta D, Fuller MJ, Marquez-Lago TT, Bachus H, Bradley JE, Weinmann AS, et al. Dynamic regulation of $\mathrm{T}$ follicular regulatory cell responses by interleukin 2 during influenza infection. Nat Immunol. 2017;18:1249-60.

24. Essig K, Hu D, Guimaraes JC, Alterauge D, Edelmann S, Raj T, et al. Roquin suppresses the PI3K-mTOR signaling pathway to inhibit T helper cell differentiation and conversion of Treg to Tfr cells. Immunity. 2017; 47:1067-1082 e1012.

25. Xu L, Huang Q, Wang H, Hao Y, Bai Q, Hu J, et al. The kinase mTORC1 promotes the generation and suppressive function of follicular regulatory $T$ cells. Immunity. 2017;47:538-551 e535.

26. Wu H, Xie MM, Liu H, Dent AL. Stat3 is important for follicular regulatory T cell differentiation. PLoS One. 2016;11:e0155040.

27. Havenar-Daughton C, Lindqvist M, Heit A, Wu JE, Reiss SM, Kendric K, et al. CXCL13 is a plasma biomarker of germinal center activity. Proc Natl Acad Sci U S A. 2016;113:2702-7.

28. Mabuka JM, Dugast AS, Muema DM, Reddy T, Ramlakhan Y, Euler Z, et al. Plasma CXCL13 but not B cell frequencies in acute HIV infection predicts emergence of cross-neutralizing antibodies. Front Immunol. 2017;8:1104.

29. Dedeoglu B, de Weerd AE, Huang L, Langerak AW, Dor FJ, Klepper M, et al. Lymph node and circulating T cell characteristics are strongly correlated in end-stage renal disease patients, but highly differentiated T cells reside within the circulation. Clin Exp Immunol. 2017;188:299-310.

30. Fan W, Demers AJ, Wan Y, Li Q. Altered ratio of T follicular helper cells to $T$ follicular regulatory cells correlates with autoreactive antibody response in simian immunodeficiency virus-infected rhesus macaques. J Immunol. 2018;200:3180-7.

31. Fonseca VR, Romao VC, Agua-Doce A, Santos M, Lopez-Presa D, Ferreira AC, et al. The ratio of blood $T$ follicular regulatory cells to $T$ follicular helper cells Marks ectopic lymphoid structure formation while activated follicular helper T cells indicate disease activity in primary Sjogren's syndrome. Arthritis Rheumatol. 2018;70:774-84.

32. van Besouw NM, Yan L, de Kuiper R, Klepper M, Reijerkerk D, Dieterich M, et al. The number of donor-specific IL-21 producing cells before and after transplantation predicts kidney graft rejection. Front Immunol. 2019;10:748,

\section{Publisher's Note}

Springer Nature remains neutral with regard to jurisdictional claims in published maps and institutional affiliations.

Ready to submit your research? Choose BMC and benefit from:

- fast, convenient online submission

- thorough peer review by experienced researchers in your field

- rapid publication on acceptance

- support for research data, including large and complex data types

- gold Open Access which fosters wider collaboration and increased citations

- maximum visibility for your research: over $100 \mathrm{M}$ website views per year

At $\mathrm{BMC}$, research is always in progress.

Learn more biomedcentral.com/submissions 